\title{
CAN LAND USE CHANGES ALTER CARBON, NITROGEN AND MAJOR ION TRANSPORT IN SUBTROPICAL BRAZILIAN STREAMS?
}

\author{
Daniela Mariano Lopes da Silva ${ }^{1 *}$; Jean Pierre Henry Balbaud Ometto ${ }^{2}$; Gré de Araújo \\ Lobo $^{3}$; Walter de Paula Lima ${ }^{4}$; Marcos Augusto Scaranello ${ }^{5}$ : Edmar Mazzi5; Humberto Ribeiro \\ da Rocha ${ }^{6}$ \\ ${ }^{1}$ UESC - Depto. de Ciências Exatas e Tecnológicas, Rod. Ilhéus-Itabuna, km 16 - 45650-000 - Ilhéus, BA - Brasil. \\ ${ }^{2}$ IGBP/INPE, Av. dos Astronautas, 1758 - 12227-010 - São José dos Campos, SP - Brasil. \\ DAEE - Depto de Águas e Energia Elétrica/CTH - Centro Tecnológico de Hidráulica e Recursos Hídricos, Av. \\ Prof. Lucio Martins Rodrigues, 120 - 05508-900 - São Paulo, SP - Brasil. \\ ${ }_{5}^{4}$ USP/ESALQ - Depto. de Ciências Florestais, C.P. 9 - 13418-900 - Piracicaba, SP - Brasil. \\ ${ }_{6}^{5}$ USP/ESALQ - Lab. de Ecologia Isotópica, C.P. 96 - 13416-900 - Piracicaba, SP - Brasil. \\ ${ }^{6}$ USP - Depto. de Ciências Atmosféricas, R. do Matão, 1226, Cidade Universitária - 05508-900 - São Paulo, SP - \\ Brasil. \\ *Corresponding author 〈dmlsilva@gmail.com>
}

ABSTRACT: Several studies in tropical watersheds have evaluated the impact of urbanization and agricultural practices on water quality. In Brazil, savannas (known regionally as Cerrados) represent $23 \%$ of the country's surface, representing an important share to the national primary growth product, especially due to intense agriculture. The purpose of this study is to present a comprehensive evaluation, on a yearly basis, of carbon, nitrogen and major ion fluxes in streams crossing areas under different land use (natural vegetation, sugar cane and eucalyptus) in a savanna region of SE Brazil. Eucalyptus and sugar cane alter the transport of the investigated elements in small watersheds. The highest concentration of all parameters (abiotic parameters, ions, dissolved organic carbon - DOC - and dissolved inorganic carbon - DIC) were found in Sugar Cane Watersheds (SCW). The observed concentrations of major cations in Eucalyptus Watersheds (EW) $(\mathrm{Mg}, \mathrm{Ca}, \mathrm{K}, \mathrm{Na})$, as well as DIN and DOC, were found frequently to be intermediate values between those of Savanna Watersheds (SW) and SCW, suggesting a moderate impact of eucalyptus plantations on the streamwater. Same trends were found in relation to ion and nutrient fluxes, where the higher values corresponded to SCW. It is suggested that sugar cane plantations might be playing an important role in altering the chemistry of water bodies.

Key words: savanna, nutrients, watershed, sugar cane, eucalyptus

\section{MODIFICAÇÕES NO USO DA TERRA PODEM ALTERAR O TRANSPORTE FLUVIAL DE CARBONO, NITROGÊNIO E ÍONS MAIORES?}

RESUMO: Diversos estudos têm sido desenvolvidos em bacias de drenagem tropicais no intuito de avaliar o impacto da urbanização e das práticas agrícolas na qualidade dos corpos d'água. No Brasil, as savanas (conhecidas regionalmente como Cerrado) representam 23\% do território brasileiro, sendo uma região importante no crescimento nacional, especialmente devido às intensas atividades agrícolas. A finalidade deste trabalho é apresentar uma avaliação dos fluxos de carbono, nitrogênio e principais íons em córregos com diferentes usos do solo (vegetação, cana de açúcar e eucalipto) em uma região de Cerrado, SE Brasil. A cana de açúcar e o eucalipto alteram o transporte dos elementos investigados nessas pequenas bacias de drenagem. As concentrações mais elevadas de todos os parâmetros analisados (parâmetros abióticos, íons, carbono orgânico dissolvido e carbono inorgânico dissolvido) foram encontradas na bacia de cana de açúcar (SCW). As concentrações observadas para os cátions na bacia do eucalipto (EW) ( $\mathrm{Mg}, \mathrm{Ca}, \mathrm{K}, \mathrm{Na})$, assim como Carbono Inorgânico Dissolvido (CID) e Carbono Orgânico Dissolvido (COD), apresentaram valores intermediários entre as bacias do Cerrado e da cana de açúcar, sugerindo um impacto moderado dessa plantação aos corpos d'água. Mesma tendência foi observada para os fluxos de íons e nutrientes, sendo, novamente, os maiores valores encontrados na bacia de cana-de-açúcar. Os autores sugerem que o cultivo da cana de açúcar representa um importante fator na modificação da química de pequenas bacias de drenagem.

Palavras-chave: Cerrado, nutrientes, bacia de drenagem, cana-de-açúcar, eucalipto 


\section{INTRODUCTION}

Small watersheds represent an important topographic condition to appraise land use change impacts related to the transport of elements such as carbon $(\mathrm{C})$ nitrogen $(\mathrm{N})$ phosphorus $(\mathrm{P})$ oxygen $(\mathrm{O})$ and sulphur (S) in aquatic systems (Galloway, 1998; Galloway et al., 2003). Therefore, evaluation of water chemistry and nutrient dynamics in streams under different land uses provides a better estimate of how anthropogenic factors affect the cycling of these elements and ecological processes. Climate, hydrology, soil properties, geomorphology, topography, soil covering and land use are the main factors altering stream water conditions (Ometto et al., 2000; McKee et al., 2001; Likens \& Buso, 2006). Reports on carbon and nitrogen budgets in small watersheds, where channel conditions are less variable than in meso-scale watersheds, are widely found in the literature (McDowell \& Asbury, 1994; Alexander et al., 2000; Biggs et al., 2004). In addition, studies in tropical watersheds are generally related to the impact of urbanization and agricultural practices on water quality (Krusche et al., 1997; Ballester et al., 1999; Markevitz et al., 2000; Daniel et al., 2002; Marques et al., 2003; Biggs et al., 2004; Mokaya et al., 2004; Thomaz et al., 2004).

The functioning of stream ecosystems can potentially decrease in tropical savanna watersheds where agricultural practices are common. In Brazil, cerrado regions represent $23 \%$ of the country's surface, representing an important share to the national primary growth product, especially due to intense agriculture. The change of natural vegetation in the Brazilian cerrado for agricultural use is associated to the increasing production of grain crops, sugar cane and eucalyptus (Klink \& Machado, 2005). Among this, sugar cane is one of the most important agricultural commodities in Brazil and covers 5 million hectares, $50 \%$ of them located in the state of São Paulo (Oliveira et al., 2000). On top of this, the intense displacement of the cerrado natural vegetation by forestry activities has called attention of the general public, increasing pressure over paper and cel- lulose companies concerning the impacts on water resources (Espirito Santo, 1995; Vital et al., 1999; Câmara et al., 2000). The purpose of this study is to present a comprehensive evaluation of carbon, nitrogen and major ion fluxes in streams crossing areas of different land use (natural vegetation, sugar cane and eucalyptus) in a savanna region in southeastern Brazil. The understanding of nutrient dynamics in these systems can provide a basis for better management practices in these watersheds.

\section{MATERIAL AND METHODS}

The study was conducted in three watersheds with different patterns of land use (Table 1 and Figure 1), located at Santa Rita do Passa Quatro, São Paulo State, Brazil. The soil is an Ustox according Soil Survey Staff (1990) and Ruggiero et al. (2002) and the annual rainfall is around $1300 \mathrm{~mm}$ year ${ }^{-1}$ with the altitude varying from 660 to $730 \mathrm{~m}$ (Oliveira et al., 1982; Pivello et al., 1998; Rocha et al., 2002).

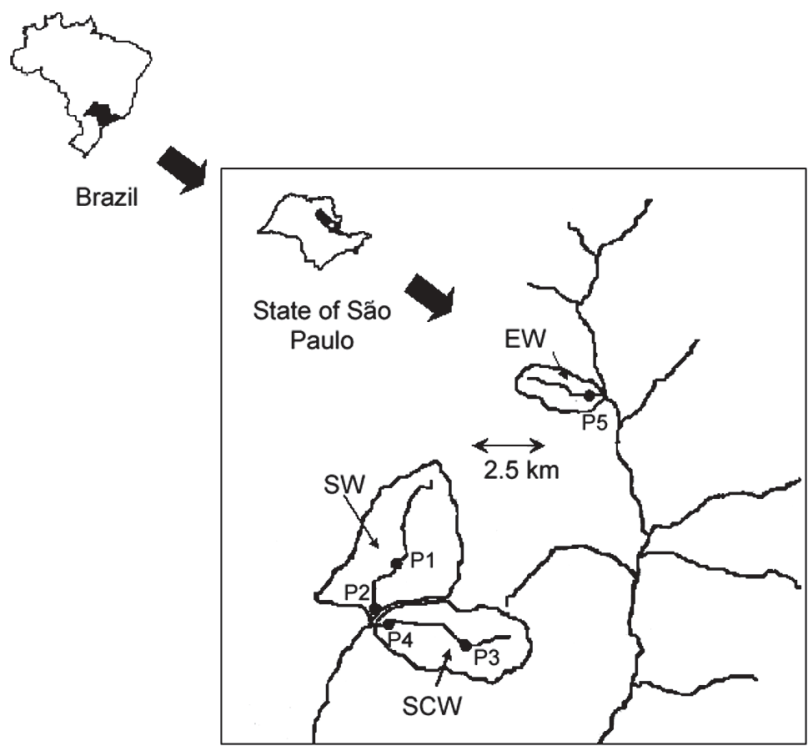

Figure 1 - Map of the savanna (SW - P1 and P2), sugar cane (SCW - P3 and P4) and eucalyptus (EW - P5) watershed indicating the sampling stations.

Table 1 - Characteristics of the savanna (SW), sugar cane (SCW) and eucalyptus (EW) watersheds.

\begin{tabular}{llccl}
\hline & Watershed & Lat/Long & Area & \multicolumn{1}{c}{ Land use } \\
\hline P1 & & ha & \\
P2 & Paulicéia & $\mathrm{S} 21^{\circ} 38^{\prime} 85^{\prime \prime} / \mathrm{W} 47^{\circ} 38^{\prime} 09^{\prime \prime}$ & 1150 & Savanna (SW) \\
P3 & Paulicéia & $\mathrm{S} 21^{\circ} 39^{\prime} 47^{\prime \prime} / \mathrm{W} 47^{\circ} 37^{\prime} 56^{\prime \prime}$ & 1750 & Savanna-Eucalyptus transition (SW) \\
P4 & Água Santa & $\mathrm{S} 21^{\circ} 40^{\prime} 11^{\prime \prime} / \mathrm{W} 47^{\circ} 36^{\prime} 87^{\prime \prime}$ & 287 & Sugar Cane (SCW) \\
P5 & Água Santa & $\mathrm{S} 22^{\circ} 69^{\prime} 55^{\prime \prime} / \mathrm{W} 47^{\circ} 01^{\prime} 87^{\prime \prime}$ & 1200 & Sugar Cane (SCW) \\
\hline
\end{tabular}


Savanna watershed (SW: P1 and P2): The study was carried out at the Paulicéia stream which is covered by natural vegetation described as Cerrado "sensu strictu" (79\%). Fabaceae, Asteraceae, Poaceae and Rubiaceae are the main families found in this reserve (Batalha et al., 2001).

Sugar Cane watershed (SCW: P3 and P4): The watershed area is covered by sugar cane crop and the stream Agua Santa is a tributary of the Paulicéia stream. Two sampling stations were chosen in this watershed, one located close to head waters of the stream (P3) and the second (P4) near to the confluence with the Paulicéia stream (SW).

Eucalyptus watershed (EW: P5): The watershed area is 423 ha of eucalyptus planted in 2003, composed of clones and hybrids of Eucalyptus grandis W. Hill ex Maiden and Eucalyptus urophylla S.T.Blake.

Streamflow was measured at P1 (SW) and P5 (EW) through automatic stream-gauging stations equipped with $\mathrm{V}$-notch weirs; the other sites measurements were made with current meters, by the discharge-area method. Monthly discharges at all five points were obtained simultaneously with water samplings. It is understood that the adopted sampling protocol is not ideal for stream systems of the dimension of those here studied, however results were very promising and will be used for the establishment of future intensive sampling routines. The results at this stage, allowed the calculation of annual watershed water yield and element fluxes.

Water samples were collected monthly from June 2005 to May 2006 at the five stations (one sample per station). Abiotic parameters including $\mathrm{pH}$, electrical conductivity, dissolved oxygen and temperature were measured in the field at sampling time. Samples for nutrient and chemical parameters were collected and immediately stored at low temperature for transporting to the laboratory.

Samples for Dissolved Organic Carbon (DOC) were passed through glass fiber filters $(0.7 \mu \mathrm{m}$ nominal pore diameter) and analyzed in a Shimadzu TOC 5000A. Samples for dissolved inorganic carbon (DIC) were passed through cellulose acetate filters $(0.45 \mu \mathrm{m}$ pore diameter) and also analyzed by the Shimadzu model TOC 5000A, with an infrared detector.

Samples for the determination of major ions $\left(\mathrm{Ca}^{2+}, \mathrm{Mg}^{2+}, \mathrm{Na}^{+}, \mathrm{K}^{+}, \mathrm{NH}_{4}^{+}, \mathrm{NO}_{3}^{2-}, \mathrm{NO}_{2}^{-}, \mathrm{Cl}^{-}, \mathrm{SO}_{4}^{2-}\right.$, $\mathrm{PO}_{4}^{3-}$ ) were passed through cellulose acetate filters and analyzed for ionic conductivity with a DIONEX
DX500. $\mathrm{HCO}_{3}$ concentration was calculated from $\mathrm{pH}$ measurements, temperature and DIC concentrations. DIN (Dissolved Inorganic Nitrogen) was taken as the sum of $\mathrm{NH}_{4}^{+}, \mathrm{NO}_{3}^{2-}$ and $\mathrm{NO}_{2}^{-}$.

Monthly water discharge was measured for each watershed. The annual DOC, DIN ion exports per unit area was calculated dividing the annual flow ( $\mathrm{N}$ concentration $\times$ discharge) by the area of the watershed.

The Tukey honest significant difference (HSS) test $(P<0.05)$ (Statistics software) was applied to test for statistically significant seasonal differences and for differences between watersheds.

\section{RESULTS AND DISCUSSION}

Abiotic parameters show distinct values based on the land type and use (Table 2). The values of conductivity, as well as $\mathrm{pH}$, tend to be higher for SCW (P3 and P4) $(P<0.05)$. The SW presented low ionic content with water electrical conductivity values varying from 5.5 to $6.6 \mu \mathrm{S} \mathrm{cm}^{-1}$ for $\mathrm{P} 2$ and $\mathrm{P} 1$, respectively. These results coincide with values found in streams located in Cerrados of other regions of Brazil (i.e. Mato Grosso state and Brasilia District) with low conductivity, $\mathrm{pH}$ and ion concentrations (Wantzen, 2003; Parron, 2004). The $\mathrm{pH}$ values in the studied streams ranged from 5.2 to 6.5 , with higher values for SCW as compared to EW and SW. The EW presented intermediate values in relation to all parameters (Table 2).

Seasonal differences were not found during the study period. The streamwater chemistry followed the same pattern as abiotic parameters with higher ion concentrations for SCW $(P<0.05)$, with the exception of $\mathrm{NH}_{4}^{+}$with concentrations always below the liquid chromatograph detection limits $(<2.7 \mu \mathrm{M})$. Streamwater nitrate $\left(\mathrm{NO}_{3}^{-}\right)$was different between SW and SCW and between SW and EW but not between SCW and EW showing that both eucalyptus and sugar

Table 2 - Abiotic parameters for savanna (SW - P1 and P2), sugar cane (SCW - P3 and P4) and eucalyptus $(\mathrm{EW}-\mathrm{P} 5)$ watersheds (mean $\pm \mathrm{sd})$.

\begin{tabular}{ccccc}
\hline & $\mathrm{pH}$ & Cond & $\mathrm{DO}$ & Temp \\
\hline & & $\mu \mathrm{S} \mathrm{cm}^{-1}$ & $\mathrm{mg} \mathrm{L}^{-1}$ & ${ }^{\circ} \mathrm{C}$ \\
P1 & $5.2 \pm 0.2$ & $6.6 \pm 1.1$ & $7.1 \pm 0.5$ & $22.9 \pm 1.9$ \\
P2 & $5.4 \pm 0.3$ & $5.5 \pm 0.5$ & $8.1 \pm 0.5$ & $21.5 \pm 1.7$ \\
P3 & $6.5 \pm 0.5$ & $58.8 \pm 6.7$ & $8.1 \pm 0.5$ & $21.4 \pm 1.8$ \\
P4 & $6.4 \pm 0.2$ & $55.9 \pm 4.5$ & $7.6 \pm 0.6$ & $22.6 \pm 0.7$ \\
P5 & $5.2 \pm 0.4$ & $10.3 \pm 2.4$ & $6.7 \pm 0.5$ & $21.7 \pm 1.9$ \\
\hline
\end{tabular}

Cond (conductivity); DO (dissolved oxygen), Temp (temperature) 
cane plantations might be playing an important role in altering the chemistry of the water bodies. The soils of Brazilian savannas are generally deep and chemically poor, with high aluminum saturation and low cation exchange capacity (Nardoto \& Bustamante, 2003). Therefore, mineralization and nitrification rates tend to be low with a slight trend to $\mathrm{N}$ immobilization (Silva, 2005). Traditionally in the forest industry, the soil tillage for eucalyptus planting involves the addition of ammonium sulphate and urea as nitrogen sources. Total available nitrogen in soil after harvesting eucalyptus is five times higher than the total nitrogen derived from natural process such as litterfall decomposition (Câmara et al., 2000). Sugar cane crops in Brazil are fertilized with nitrogen in rates from 60 to $120 \mathrm{~kg} \mathrm{~N}$ $\mathrm{ha}^{-1}$, from different fertilizers sources, depending on the region and economic aspects (Oliveira et al., 2000). Thus, the application of nitrogen based fertilizer could favor an increase of the net mineralization and nitrification rates, enhancing the nitrate concentration in the streamwater, as observed in the data here collected.

The concentration of $\mathrm{Mg}\left(\mathrm{r}^{2}=0.42\right)$ and $\mathrm{Ca}$ $\left(r^{2}=0.46\right)$ were correlated to conductivity (Figure 2$)$, and again SCW presented the highest values of these cations (Figure 2). Agricultural use of limestone is a common practice in sugar cane and eucalyptus plantations in Brazil, with the major objective of changing soil $\mathrm{pH}$, neutralizing toxic effects of $\mathrm{Al}$ and $\mathrm{Mn}$, which could determine losses of crop productivity (Prado et al., 2002). Potassium, chloride and sulphate were also higher for SCW $(P<0.05)$ and probably are due to the application of $\mathrm{KCl}$ or $\mathrm{KSO}_{4}$ as fertilizers, or to the use of "vinhaça" for irrigation, a waste product of alcohol production, which has a high potassium concentration. Erosive processes due the permanently exposed soil during the initial phase of soil preparation in sugar cane cultivation can contribute to

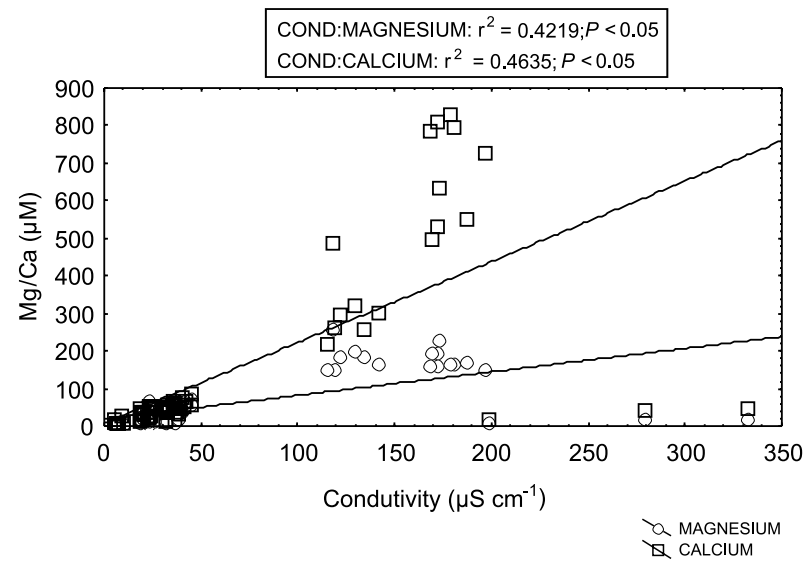

Figure 2 - Correlation between $\mathrm{Mg} / \mathrm{Ca}$ and conductivity at savanna (SW - P1 and P2), sugar cane (SCW - P3 and P4) and eucalyptus (EW - P5) watershed. these high ion concentrations in stream water, corroborating with our findings for SCW (Politano \& Pizarra, 2005).

The intermediate values of concentration between SW and SCW for major cations in EW $(\mathrm{Mg}$, $\mathrm{Ca}, \mathrm{K}, \mathrm{Na}$ ) suggest a moderate impact on streamwater. At this point it is important to mention that different patches of soil types are found in the studied areas (Hung K. Chang, UNESP, personal communication). In general, eucalyptus is cultivated in Brazil in areas with low soil fertility. To prevent decreases in productivity during the exploitation period of the crop, elements such as nitrogen, potassium and phosphorus and micronutrients such as boron and zinc (although these latest with a lower frequency) are applied to these soils before cultivation, potentially increasing the concentration of these elements in soil solution and consequently in the streamwater. Studies carried out at experimental watersheds covered with eucalyptus plantations in other regions of the São Paulo State $\left(23^{\circ} 25^{\prime} \mathrm{S}\right.$ and $45^{\circ} 56^{\prime} \mathrm{W}$ - Vale do Paraíba) showed higher values of $\mathrm{Na}, \mathrm{K}, \mathrm{Mg}$ and $\mathrm{Ca}$ than the values observed in this study (Ranzini \& Lima, 2002). The authors report a surface runoff process occurring in the region, which suggests a nutrient flow to the stream. This process, associated to soil chemical characteristics and fertilization, could explain the differences found between these studies. It is however important to highlight that forestry is altering stream water composition in these watersheds.

There were no differences on DOC concentrations among the watersheds, however DIC presented higher values for SCW $(P<0.05)$. The clear cutting, common practice during eucalyptus harvests, has been criticized in the literature because of nutrient cycling concerns and changes in soil properties (McLaughlin $\&$ Phillips, 2006). Ciglasch et al. (2004) observed changes in DOM (Dissolved Organic Matter) dynamics due to forestry activities in Brazilian Cerrados of the Minas Gerais state, where higher DOM concentrations were observed in soil solution under pinus plantations as compared to native Cerrados. The faster mineralization of the soil organic matter under pine plantation and/or stronger retention of DOM in the Cerrado mineral soil, are possible explanations. A similar pattern was found by Neu (2005) studying tropical forests in the Manaus region, where higher concentration of DOC in soil solution under areas of forest plantation, compared to "terra-firme" primary forest, resulted from fertilizer application (NPK). Both, pinus and eucalyptus plantations in Brazil are normally produced in soils of low fertility from Cerrado regions, therefore, despite specific fertilization needs for each of these crops, the soil preparation for the activity re- 
quires application of fertilizers based on nutrients $(\mathrm{N}$, $\mathrm{P}$ and $\mathrm{K}$ ), and use of limestone to correct soil $\mathrm{pH}$.

On average, the DIC concentrations range form about $53 \mu \mathrm{M}$ for the EW stream to about 350 $\mu \mathrm{M}$ in the SCW stream, although considering the downstream station in SW (P2) no difference was found when comparing to EW (P5). This is probably associated to the fact that in the P2 drainage area a transition from Cerrado to eucalyptus plantation is found, which could indicate the contribution of this land use to the stream inorganic carbon pool, or changes of in-stream respiration processes in the lower reach of the SW stream. Despite changes in soil characteristics, a good correlation between DIC and conductivity was observed, with the higher concentration of conductivity for SCW (Figure 3), showing that the landscape is the main factor of DIC concentration increase. More pronounced differences among the watersheds were associated to the $\mathrm{HCO}_{3}$ form, with higher concentration in $\mathrm{P} 3$ and $\mathrm{P} 4(P<0.05)$, where $\mathrm{pH}$ had the highest values, ranging from 6.4 to 6.5 (Table 2).

Nitrogen loading to a stream is dependent on land use, presence of nitrogen fixing crops in the watershed, fertilizer application, fossil fuel burning and population density (Howarth et al., 1996; Galloway, 1998; Galloway et al., 2003). In this study, nitrate contributed to most of dissolved inorganic nitrogen (DIN) followed by nitrite and ammonium, in all systems. The highest DIN concentrations were found for SCW $(P<0.05)$, varying from $42.2 \mu \mathrm{M}$ (P4) to $48.6 \mu \mathrm{M}$ (P3) and for EW $(33.7 \mu \mathrm{M})$. In relation to other chemi- cal parameters, the lowest DIN concentrations were found at the SW watershed. Previous studies at SW (P1) showed that the $\mathrm{N}$ export is dominated by organic nitrogen forms representing $80 \%$ of the total nitrogen (Silva, 2005), suggesting the low nutrient availability of these ecosystems and that the inorganic forms are rapidly absorbed by the vegetation.

The higher DIN fluxes were found for SCW and EW, with rates ranging from $1-2 \mathrm{~kg} \mathrm{ha}^{-1} \mathrm{yr}^{-1}$, and the lower fluxes for SW $\left(0.8-0.9 \mathrm{~kg} \mathrm{ha}^{-1} \mathrm{yr}^{-1}\right)$. Comparing these with tropical streams from Puerto Rico (Tabonuco and Colorado forest, McDowell \& Asbury, 1994) and from Southeastern Brazil (Ombrophilus Dense Forest, Silva, 2005) these fluxes are considered low. Nitrogen fluxes in Ombrophilus

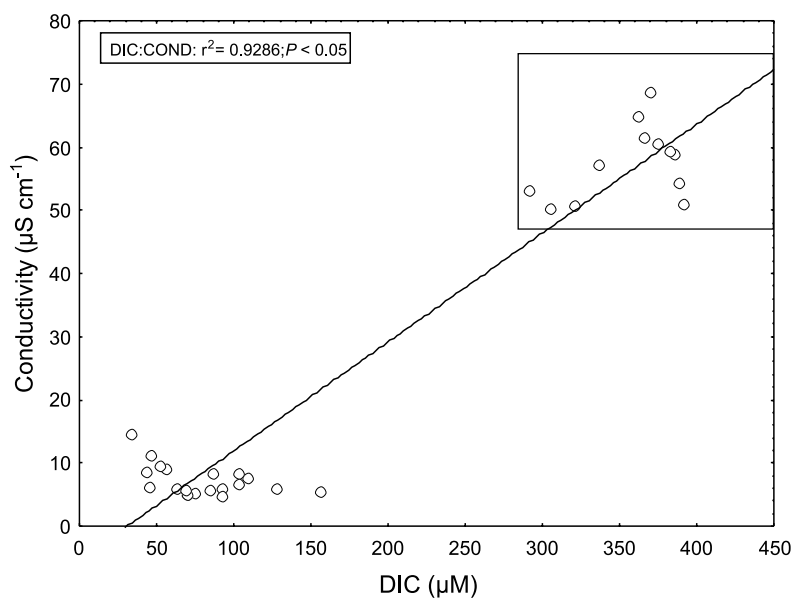

Figure 3 - Correlation between DIC (Dissolved Inorganic Carbon) and conductivity at savanna (SW), sugar cane (SCW in detail) and eucalyptus (EW) watersheds.

Table 3 - Mean concentration of cations and anions for savanna (SW - P1 and P2), sugar cane (SCW - P3 and P4) and eucalyptus $(\mathrm{EW}-\mathrm{P} 5)$ watersheds $(\mathrm{n}=12)($ mean $\pm \mathrm{sd})(\mathrm{n}=12)$.

\begin{tabular}{|c|c|c|c|c|c|}
\hline & SW & & $\mathrm{SCW}$ & & EW \\
\hline & P1 & P2 & P3 & P4 & P5 \\
\hline & - & - & $\ldots \mu$ & - & - \\
\hline $\mathrm{Cl}$ & $14.4 \pm 11.3$ & $10.6 \pm 4.2$ & $132.2 \pm 26.0$ & $144.7 \pm 31.8$ & $25.4 \pm 22.8$ \\
\hline $\mathrm{NO}_{2}$ & $2.7 \pm 0.8$ & $2.4 \pm 0.4$ & $9.4 \pm 0.8$ & $10.0 \pm 1.2$ & $2.1 \pm 0.5$ \\
\hline $\mathrm{SO}_{4}$ & $1.1 \pm 0.2$ & $1.0 \pm 0.1$ & $4.6 \pm 1.5$ & $5.4 \pm 1.5$ & $1.0 \pm 0.1$ \\
\hline $\mathrm{NO}_{3}$ & $2.2 \pm 0.9$ & $7.5 \pm 0.7$ & $39.2 \pm 11.6$ & $32.2 \pm 6.1$ & $33.7 \pm 8.2$ \\
\hline $\mathrm{Na}$ & $27.1 \pm 17$ & $22.2 \pm 7.6$ & $83.8 \pm 16.4$ & $99.8 \pm 21.5$ & $39.2 \pm 32.1$ \\
\hline $\mathrm{NH}_{4}$ & $<2.7$ & $<2.7$ & $<2.7$ & $<2.7$ & $<2.7$ \\
\hline K & $11.9 \pm 7.5$ & $9.5 \pm 1.8$ & $73.4 \pm 42.5$ & $48.1 \pm 23.5$ & $13.9 \pm 2.5$ \\
\hline $\mathrm{Mg}$ & $3.1 \pm 2.7$ & $2.9 \pm 1.4$ & $75.9 \pm 12.9$ & $92.5 \pm 16.3$ & $10.7 \pm 2.7$ \\
\hline $\mathrm{Ca}$ & $3.5 \pm 2.0$ & $4.3 \pm 2.4$ & $72.6 \pm 10.4$ & $86.9 \pm 14.2$ & $10.4 \pm 3.3$ \\
\hline $\mathrm{HCO}_{3}$ & $4.0 \pm 1.2$ & $5.6 \pm 3.7$ & $146.2 \pm 106.8$ & $148.7 \pm 46.3$ & $3.6 \pm 4.5$ \\
\hline DIC & $104.4 \pm 34.4$ & $75.5 \pm 11.7$ & $315.6 \pm 130.3$ & $349.7 \pm 43.1$ & $52.8 \pm 18.2$ \\
\hline DOC & $122.5 \pm 126.8$ & $142.0 \pm 168.5$ & $185.9 \pm 134.5$ & $268.4 \pm 108.4$ & $115.0 \pm 117.9$ \\
\hline
\end{tabular}

DIC (Dissolved Inorganic Carbon), DOC (Dissolved Organic Carbon). 
dense forest (Atlantic Forest) presented values varying from 2 to $4 \mathrm{~kg} \mathrm{ha}^{-1} \mathrm{yr}^{-1}$ which coincide with EW and SCW, considered disturbed watersheds. It has been shown in several studies that forests have higher availability of $\mathrm{N}$ as compared to savanna (Nardoto \& Bustamante, 2003; Bustamante et al., 2004; Silva, 2005). Low $\mathrm{N}$ export from these watersheds is probably due to the eucalyptus cultivation and the high $\mathrm{N}$ retention capacity. This cultivation accumulates high quantities of $\mathrm{N}$ in wood, branches and leaves and low quantities are exported to streamwaters (Vital et al., 1999; Câmara et al., 2000).

Although no differences were found in DOC concentration of stream waters (Table 3 ), the carbon flux in the SCW (P4) is higher as compared to EW and SW (Table 4). As expected, the lowest concentration of DOC was found at Savanna watershes (P1), since at this station the lowest ion concentration was found. Again, intermediate values were found for EW (7.9 $\left.\mathrm{kg} \mathrm{ha}^{-1} \mathrm{yr}^{-1}\right)$. Watersheds domi-

Table 4 - DOC, DIN and major ion fluxes for savanna (SW - P1 and P2), sugar cane (SCW - P3 and P4) and eucalyptus (EW - P5) watersheds.

\begin{tabular}{lrrrrrrr}
\hline $\begin{array}{l}\text { Sample } \\
\text { Station }\end{array}$ & DOC & DIN & Cl & Na & K & Mg & Ca \\
\hline & $-1 .-1$ & & & & \\
P1 & 4.9 & 0.2 & 1.4 & 1.7 & 1.2 & 0.2 & 0.4 \\
P2 & 7.0 & 0.5 & 1.2 & 1.5 & 1.1 & 0.2 & 0.5 \\
P3 & 7.2 & 2.1 & 13.5 & 5.0 & 8.7 & 3.7 & 7.9 \\
P4 & 11.6 & 2.1 & 16.1 & 7.1 & 1.7 & 6.7 & 10.9 \\
P5 & 7.9 & 2.1 & 2.9 & 2.8 & 1.7 & 0.8 & 1.3 \\
\hline
\end{tabular}

DOC (dissolved organic carbon) DIN (dissolved inorganic nitrogen) nated by intensive agriculture export a large quantity of soil sediments to water bodies (Vital et al., 1999; Ranzini \& Lima, 2002), carrying along nutrients and associated organic matter. The reduced organic matter degradation and the slower mineralization process under forested regions and probably for sugar cane compared to savannas could be due to the fact that these crops are non-native species (Wilcke \& Lilienfein, 2002).

Major ion fluxes presented the same pattern of nutrient fluxes with higher values found for SCW watershed followed by EW and SW. Studies comparing the impact of land use in small watersheds in Brazil are scarce. Several studies have been developed at eucalyptus watersheds (Ranzini \& Lima, 2002; Câmara et al., 2000; Vital et al., 1999), however little is known about the impacts of sugar cane in these ecosystems. Table 5 presents a comparison of some studies carried out in Brazil, with different characteristics of land use, showing the role of sugar cane and eucalyptus plantations in streamwater chemistry. Streams located in savanna ecosystems and sugar cane crops did not differ from those presented in this work. However the ionic concentration found in a eucalyptus plantation stream, in Vale do Paraíba (SP), were considerably higher than those observed for EW (Ranzini \& Lima, 2002).

\section{CONCLUSIONS}

Eucalyptus and sugar cane crops alter the transport of elements in small watersheds of savanna regions. Streams draining sugar cane crops show higher concentration of all analyzed elements as compared to the eucalyptus and savanna streams. The

Table 5 - Comparison of abiotic parameters ( $\mathrm{pH}$ and conductivity) and ions $(\mu \mathrm{M})$ between Brazilian watersheds with different land uses (ref: references).

\begin{tabular}{lcccccccccccc}
\hline Brazilian watersheds & Land Use & $\mathrm{pH}$ & $\mathrm{Cond}$ & $\mathrm{Cl}$ & $\mathrm{NO}_{2}$ & $\mathrm{SO}_{4}$ & $\mathrm{NO}_{3}$ & $\mathrm{Na}$ & $\mathrm{K}$ & $\mathrm{Mg}$ & $\mathrm{Ca}$ & $\mathrm{ref}$ \\
\hline Sta Rita do Passa Quatro & Savanna & 5 & 6 & 4 & - & 1 & 1.7 & 5 & 10 & 3 & 9 & 1 \\
Brasília & Savanna & - & - & 8 & - & 0.2 & 0.08 & 8 & 2 & 4 & 10 & 2 \\
Mato Grosso & Savanna & - & 5 & - & - & - & $<0.81$ & - & - & - & - \\
Sta Rita do Passa Quatro & Savanna & 5.2 & 6.6 & 15 & 2.5 & 1.0 & 1.8 & 31.3 & 11.1 & 2.8 & 3.5 & Actual \\
Sta Rita do Passa Quatro & Savanna & 5.4 & 5.5 & 11 & 2.4 & 1.0 & 7.3 & 23.7 & 9.1 & 2.6 & 4.4 & Actual \\
Piracicaba & Sugar Cane & - & - & 87 & - & 37 & 6 & 136 & - & 133 & 193 & 4 \\
Sta Rita do Passa Quatro & Sugar Cane & 6.5 & 59 & 133 & 9.4 & 3.9 & 38.1 & 88.3 & 75.2 & 74.5 & 73.3 & Actual \\
Sta Rita do Passa Quatro & Sugar Cane & 6.4 & 56 & 143 & 10.2 & 5.1 & 32.3 & 101.7 & 45.4 & 93.6 & 88.7 & Actual \\
Luiz Antonio & Eucalyptus & 5.2 & 10 & 27 & 2.3 & 1.0 & 33.9 & 42.5 & 13.9 & 10.9 & 10.8 & Actual \\
Vale do Paraíba & Eucalyptus & 5.9 & 44 & - & - & - & 8.2 & 97 & 49 & 22.2 & 46 & 5 \\
Vale do Paraíba & Eucalyptus & 5.8 & 36 & - & - & - & 4.9 & 91.3 & 34.5 & 21 & 22 & 5 \\
\hline
\end{tabular}

1- Silva, 2005; 2-Parron, 2004; 3- Wantzen, 2003; 4- Ometto et al., 2000; 5- Ranzini \& Lima, 2002 
monitoring of stream water chemistry is an important tool to understand ecological and anthropogenic dynamics of the use of Cerrado ecosystems in Brazil, as well as constructing predictions of water resources quality and availability for future generations.

\section{ACKNOWLEDGMENTS}

To the BIOTA-FAPESP Program for financial support (FAPESP project $n^{\circ}$ 02/09289-9). To Fabiana Fracassi, Andréa Silva and Alexandra A. Montebello for helping in laboratory assistance and the technical support of Dr. M.Z. Moreira (CENA - USP).

\section{REFERENCES}

ALEXANDER, R.B.; SMITH, R.A.; SCHWARZ, G.E. Effects of stream channel size on the delivery of nitrogen to the Gulf of Mexico. Nature, v.403, p.758-761, 2000.

BALLESTER, M.V.; MARTINELLI, L.A.; KRUSCHE, A.V.; VICTORIA, R.L.; BERNARDES, M.; CAMARGO, P.B. Effects of increasing organic matter loading on the dissolved O-2, free dissolved $\mathrm{CO} 2$ and respiration rates in the Piracicaba River basin, southeast Brazil. Water Research, v.33, p.2119-2129, 1999.

BATALHA, M.A.; MANTOVANI, W. Floristic composition of the Cerrado in the Pé de Gigante reserve (Santa Rita do Passa Quatro, Southeastern of Brazil). Acta Botanica Brasilica, v.15, p.298303, 2001.

BIGGS, T.W.; DUNNE T.; MARTINELLI, L.A. Natural controls and human impacts on stream nutrient concentrations in a deforested region of the Brazilian Amazon basin. Biogeochemistry, v.68, p.227-257, 2004.

BUSTAMANTE, M.M.C.; MARTINELI, L.A.; SILVA, D.A.; CAMARGO, P.B.; KLINK, C.A.; DOMINGUES, T.F.; SANTOS, R.V. $15 \mathrm{~N}$ natural abundance in woody plants and soils of central brazilian savannas (Cerrado). Ecological Applications, v.14, p.S200-S213. 2004.

CÂMARA, C.D.; LIMA, W.P.; VIEIRA, S.A. Clearcutting of a 50 year old Eucalyptus plantation: impacts on nutrient cycling in an experimental catchment Scientia Forestalis, n.57, p.99-109, 2000.

CIGLASCH, H.; LILIENFEIN, J.; KAISER, K.; WILCKE, W. Dissolved organic matter under native Cerrado and Pinus caribaea plantations in the Brazilian savanna. Biogeochemistry, v.67, p. 157-182, 2004.

DANIEL, M.H.B.; MONTEBELLO, A.A.; BERNARDES, M.C.; OMETTO, J.P.H.B.; CAMARGO P.B.; KRUSCHE, A.V.; BALLESTER, M.V.; VICTORIA, R.L.; MARTINELLI, L.A. Effects of urban sewage on dissolved oxygen, dissolved inorganic and organic carbon, and electrical conductivity of small streams along a gradient of urbanization in the Piracicaba River Basin. Water, Air, \& Soil Pollution, v.136, p.189-206, 2002.

ESPÍRITO SANTO, C.V. Diagnóstico e avaliação de setor florestal brasileiro região Centro-Oeste: Anuário executivo. Brasília: FUNATURA; ITTO; IBAMA, 1995. 59p.

GALLOWAY, J.N. The global nitrogen cycle: changes and consequences. Environmental Pollution, v.102, p.15-24, 1998.

GALLOWAY, J.N.; ABER, J.D.; ERSIMAN, J.W.; SEITZINGER, S.P.; HOWARTH, R.W.; COWLING, E.B.; COSBY, J. The nitrogen cascade. BioScience, v.53, p.341-356, 2003.

HOWARTH, R.W.; BILLEN, G., SWANEY, D.; TOWNSEND, A.; JAWORSKI, N.; LAITHA, K.; DOWNING, J.A.; ELMGREN, R.; CARACO, N.; JORDAN, T.; BERENDSE, F.; FRENEY, J.; KUDEVAROV, V.; MURDOCH, P.; ZHU, Z.L. Regional nitrogen budgets and riverine N\&P fluxes for the drainages to the North Atlantic Ocean: Natural and human influences Biogeochemistry, v.35, p.75-139, 1996.
KLINK, C.A.; MACHADO, R.B. Conservation of the Brazilian Cerrado. Conservation Biology, v.19, p.707-713, 2005.

KRUSCHE, A.V.; CARVALHO, F.P.; MORAES, J.M.; CAMARGO, P.B.; BALLESTER, M.V.R.; HORNICK, S.; MARTINELLI, L.A. Spatial and temporal water quality variability in the Piracicaba river basin, Brazil. Journal of American Water Resource Association, v.33, p.1117-1123, 1997.

LIKENS, G.E.; BUSO, D.C. Variation in streamwater chemistry throughout the Hubbard Brook Valley. Biogeochemistry, v.78, p.1-30, 2006.

MARKEVITZ, D.; DAVIDSON, E.A.; FIGUEIREDO, R.O.; VICTORIA, R.L.; KRUSCHE, A.V. Control of cation concentrations in stream waters by surface soil processes in an Amazonian watershed. Nature, v.410, p.802-805, 2000.

MARQUES, P.H.C.; OLIVEIRA, H.T.; MACHADO, E.C. Limnological study of Piraquara river (upper Iguaçu basin): Spatio temporal variation of physical and chemical variables and watershed zoning. Brazilian Archives of Biology and Technology, v.46, p.383-394, 2003

MCDOWELL, W.H.; ASBURY, C.E. Export of Carbon, Nitrogen, and major ions from three tropical montane watersheds. Limnology and Oceanography, v.39, p.111-125, 1994.

MCLAUGHLIN, J.W.; PHILIPS, S.A. Soil carbon, nitrogen, and base cation cycling 17 years after whole-tree harvesting i $\mathrm{n}$ a low-elevation red spruce (Picea rubens)-balsam fir (Abies balsainea) forested watershed in central Maine, USA. Forest Ecology and Management, v.222, p.234-253, 2006.

MCKEE, L.J.; EYRE, B.D.; HOSSAIN, S.; PEPPERELL, P.R. Influence of climate, geology and humans on spatial and temporal nutrient geochemistry in the subtropical Richmond River catchment, Australia. Marine and Freshwater Research, v.52, p.235-248, 2001.

MOKAYA, S.K.; MATHOOKO, J.M.; LEITCHFRIED, M. Influence of anthropogenic activities on water quality of a tropical stream ecosystem. African Journal of Ecology, v.42, p.281-288, 2004.

NARDOTO, G.B.; BUSTAMANTE, M.C. Effects of fire on soil nitrogen dynamics and microbial biomass in savannas of Central Brazil. Pesquisa Agropecuaria Brasileira, v.38, p.955-962, 2003.

NEU, V. Influência da cobertura vegetal na ciclagem de nutrientes via solução do solo na região de Manaus/AM. Piracicaba: USP/ ESALQ, 2005. 110p. (MsC-Thesis).

OLIVEIRA, J.B.; PRADO, H.; ALMEIDA, C.L.F. Levantamento Pedológico Semi-detalhado do Estado de São Paulo: Quadrícula de Descalvado. (Folha SF-23-V-C-IV).Rio de Janeiro: EMBRAPA, SAA, CPA; IAC, 1982. Escala 1:100.000.

OLIVEIRA, J.C.M.; REICHARDT, K.; BACCHI, O.O.S.; TIMM, L.C.; DOURADO-NETO, D.; TRIVELIN, P.C.O.; TOMINAGA, T.T.; NAVARRO, R.C.; PICCOLO, M.C.; CÁSSARO, F.A.M. Nitrogen dynamics in a soil-sugar cane system. Scientia Agricola, v.57, p.467-472, 2000.

OMETTO, J.P.H.B.; MARTINELLI, L.A.; BALLESTER, M.V.R.; GESSNER, A.; KRUSCHE, A.V.; VICTORIA, R.L.; WILLIAMS, M. Effects of land use on water chemistry and macroinvertebrates in two streams of Piracicaba river basin, southeast Brazil. Freshwater Biology, v.44, p.327-337, 2000.

PARRON, L.M. Aspectos da ciclagem de nutrientes em função do gradiente topográfico, em uma mata de galeria no Distrito Federal. Brasília: UnB, 2004. 181p. (PhD - Thesis).

PIVELLO, V.R.; BITENCOURT, M.D.; MANTOVANI, W.; MESQUITA JR., H.N.; BATALHA, M.A.; SHIDA, C. Proposta de zoneamento ecológico para a reserva de Cerrado Pé de Gigante (Santa Rita do Passa Quatro). Brazilian Journal of Ecology, v.2, p.108-118, 1998.

POLITANO, W.; PISARRA, T.C.T. Evaluation of areas of different states of accelerated erosion of soil in sugar cane plantation and citrus orchards utilizing photointerpretation. Engenharia Agrícola, v.25, p.242-252, 2005. 
PRADO, R.M., FERNANDES, F.M.; NATALE, W. Lime and slag evaluated by leaf analysis, macronutrient accumulation and export of sugarcane. Scientia Agricola, v.59, p.129-135, 2002.

RANZINI, M.; LIMA, W.P. Comportamento hidrológico, balanço de nutrientes e perdas de solo em duas microbacias reflorestadas com Eucalyptus, no Vale do Paraíba, SP. Scientia Forestalis, v.61, p.144-159. 2002

ROCHA, H.R.; FREITAS, H.C.; ROSOLEM, R.; JUAREZ, R.N.; TANNUS, R.; LIGO, M.A.; CABRAL, O.M.R.; DIAS, M.A.F.S. Medidas de fluxo de $\mathrm{CO} 2$ em um cerrado sensu stricto no sudoeste do Brasil. Biota Neotropica, v.2, 2002. Available at: www.biotaneotropica.org.br.

RUGGiERO, P.G.C.; BATALHA, M.A.; PIVEllo, V.R.; MEIRELES, S.T. Soil-vegetation relationships in Cerrado (Brazilian savanna) and semideciduous forest, Southeastern Brazil. Plant Ecology, v.160, p.1-16, 2002.

SILVA, D.M.L. Dinâmica de nitrogênio em microbacias no Estado de São Paulo. Piracicaba: USP/ESALQ, 2005. 113p. (PhD - Thesis).

SOIL SURVEY STAFF. Keys to soil taxonomy. 10.ed. Washington, 2006. Available at: http://soils.usda.gov/technical/classification/ taxonomy/.
THOMAS, S.M.; NEILL, C.; DEEGAN, L.A.; KRUSCHE, A.; BALLESTER, M.V.R.; VICTORIA, R.L. Influences of land use and stream size on particulate and dissolved materials in a small Amazonian stream network. Biogeochemistry, v.68, p.135151, 2004.

VITAL, A.R.S.; LIMA, W.P.; POGGIANI, F.; CAMARGO, F.R.A. Biogeoquímica de uma microbacia após o corte raso de uma plantação de eucalipto de 7 anos de idade. Scientia Forestalis, n.55, p.17-28, 1999.

WANTZEN, K.M. Cerrado streams - characteristics of a threatened freshwater ecosystem type on the Tertiary Shields of Central South America. Amazoniana, v.17, p.481-502, 2003.

WILCKE, W; LILIENFEIN, J. Biogeochemical consequences of the transformation of native Cerrado into Pinus caribaea plantations in Brazil Plant and Soil, v.238; p.175-189, 2002.

Received September 29, 2006

Accepted April 20, 2007 